\title{
Cloning and Heterologous Expression of the $\beta$-Galactosidase Gene from Bifidobacterium longum RD47 in B. bifidum BGN4
}

\author{
Min Ju Park ${ }^{1}$, Myeong Soo Park ${ }^{2 *}$, and Geun Eog Ji ${ }^{1,2 *}$ \\ ${ }^{1}$ Department of Food and Nutrition, Research Institute of Human Ecology, Seoul National University, Seoul 151-742, Republic of Korea \\ ${ }^{2}$ Research Center, BIFIDO Co., Ltd., Hongcheon 205-804, Republic of Korea
}

\author{
Received: May 31, 2019 \\ Revised: September 12, 2019 \\ Accepted: September 27, 2019 \\ First published online: \\ September 30, 2019 \\ ${ }^{*}$ Corresponding authors \\ G.E.J. \\ Phone: +82-2-880-8749 \\ Fax: +82-2-884-0305 \\ E-mail: geji@snu.ac.kr \\ M.S.P. \\ Phone: +82-33-435-4962 \\ Fax: +82-33-435-4963 \\ E-mail: bifidopark@bifido.com \\ pISSN 1017-7825, eISSN 1738-8872 \\ Copyright(C) 2019 by \\ The Korean Society for Microbiology \\ and Biotechnology
}

\begin{abstract}
The gene encoding $\beta$-galactosidase was cloned from Bifidobacterium longum RD47 with combinations of several bifidobacterial promoters, and expressed in B. bifidum BGN4. Among the recombinant bifidobacteria, BGN4+G1 showed the highest $\beta$-galactosidase level, for which the hydrolytic activity was continuously 2.5 to 4.2 times higher than that of BGN4 and 4.3 to 9.6 times higher than that of RD47. The $\beta$-galactosidase activity of BGN4+G1 was exceedingly superior to that of any of the other 35 lactic acid bacteria. When commercial whole milk and BGN4+G1 were reacted, BGN4+G1 removed nearly $50 \%$ of the lactose in the milk by the $63-\mathrm{h}$ time point, and a final $61 \%$ at $93 \mathrm{~h}$. These figures are about twice the lactose removal rate of conventional fermented milk. As for the reaction of commercial whole milk and crude enzyme extract from BGN4+G1, the $\beta$-galactosidase of BGN4+G1 eliminated $51 \%$ of the lactose in milk in $2 \mathrm{~h}$. As shown below, we also compared the strengths and characteristics of the strong bifidobacterial promoters reported by previous studies.
\end{abstract}

Keywords : $\beta$-Galactosidase, lactose hydrolysis, bifidobacteria

\section{Introduction}

$\beta$-Galactosidase (lactase, E.C. 3.2.1.23) catalyzes the hydrolytic process of the terminal $\beta-1,4$-D-galactosyl residues found in $\beta$-D-galactosides, such as lactose, and releases D-glucose and D-galactose as end products [1-3]. Because it can be used to lower the amount of lactose in milk for lactose intolerant people or prevent lactose crystallization particularly at low temperature, $\beta$ galactosidase is a crucial enzyme in the dairy industry [1, 4-7]. In addition to the hydrolysis activity, some of these enzymes can be used to produce galactooligosaccharides (GOS), which are widely utilized in prebiotics, through the transgalactosylation reaction [8]. For industrial purposes, $\beta$-galactosidases are mainly extracted from microorganisms including Bifidobacterium [9, 10], although mostly from fungi. The production of $\beta$-galactosidase from microbes is a preferred choice because of a higher yield and thus the relatively inexpensive cost of the enzyme. By extension, in order for $\beta$-galactosidase to be used safely in the food industry, microorganisms producing $\beta$-galactosidase should be food-grade. From this point of view, bifidobacteria are regarded as a good source of $\beta$-galactosidase because of their GRAS (generally recognized as safe) status [11].

Bifidobacteria are representative of probiotics defined as non-pathogenic microorganisms that provide a health benefit to the host [12]. Since their first discovery by Tissier [13], these microorganisms have been extensively investigated by some scientists. Bifidobacteria are saccharolytic microorganisms, and their metabolism is associated with carbohydrate degrading enzymes, particularly glycosyl hydrolases, which enable the use of a variety of glycan substrates available in the intestines directly or indirectly [14-17]. Among the glycosyl hydrolases encoded by bifidobacteria, $\beta$-galactosidase enables bifidobacteria to utilize (human) milk and milk-based substrates, i.e., lactose, human milk oligosaccharide (HMO) and GOS [18, 19]. The hydrolysis and transgalactosylation properties of $\beta$-galactosidase for milk-based substrates have been studied in several bifidobacteria to date [9, 20-22].

Recently, the $\beta$-galactosidase activities of 43 lactic acid bacteria were assessed. Among them, Bifidobacterium longum 
RD47 was found to be one of the bifidobacterial strains with the greatest level of $\beta$-galactosidase activity [23]. The whole genome sequence of RD47 was identified, and there were three $\beta$-galactosidase genes (G1, G3, and G4) in it. The properties of hydrolysis and transgalactosylation were examined for each gene, and it was revealed that G1 showed the greatest contribution to the hydrolysis and transgalactosylation activity of RD47. The optimal $\mathrm{pH}$ and temperature for the hydrolytic activity of G1 is $\mathrm{pH} 8.5$ and $40^{\circ} \mathrm{C}$, respectively, which are moderate for activity in the human colonic environment [24]. Furthermore, G1 yielded maximum production of $\beta$-GOS [24] and an oligosaccharide with a new structure (data not shown) at $\mathrm{pH} 8.5$ and $45^{\circ} \mathrm{C}$.

In this study, we sought to obtain new recombinant bifidobacteria with significant $\beta$-galactosidase expression by inserting several bifidobacterial promoters upstream of the G1. These bacteria were employed to remove lactose in the milk for use in a future study to determine whether the alleviation of lactose intolerance depends on the $\beta$ galactosidase activity of bifidobacteria. Incidentally, we compared the strength and characteristics of several bifidobacterial promoters which are known to be constitutively strong as shown by previous studies.

\section{Materials and Methods}

\section{Bacterial Strains, Plasmid DNA and Culture Conditions}

The bacterial strains and plasmids used in this study are listed in Table 1. E. coli were grown at $37^{\circ} \mathrm{C}$ in Luria-Bertani (LB) medium (BD Difco, USA) with shaking at $150 \mathrm{rpm}$. Bifidobacteria were cultured at $37^{\circ} \mathrm{C}$ in Man Rogosa Sharpe (MRS) medium (BD Difco) containing $0.05 \%$ L-cysteine $\cdot \mathrm{HCl}$ (Sigma Aldrich, USA).

Antibiotics were used at the following concentrations: $100 \mu \mathrm{g} / \mathrm{ml}$ ampicillin (Bio Basic Inc., Canada) for E. coli and $3 \mu \mathrm{g} / \mathrm{ml}$ chloramphenicol (Duchefa, The Netherlands) for bifidobacteria.

\section{DNA Molecular Cloning and Transformation}

The target DNA fragments were amplified using TAKARA PrimeSTAR GXL DNA Polymerase (TAKARA, Japan), and each primer set is listed in Table 2. First, the DNA fragment encoding the $\beta$-galactosidase, G1, was PCR-amplified with primer G1 from genomic DNA of B. longum RD47 and cloned into pBES2 via XbaI and EcoRI to construct $\mathrm{pB}-\mathrm{G} 1$. Second, the DNA fragment encoding the $\beta$-galactosidase open reading frame (ORF) without the promoter, G1ORF, was PCR amplified with primer G1ORF from genomic DNA of RD47 and cloned into pBES2 via KpnI and EcoRI to construct $\mathrm{pB}-\mathrm{G} 1 \mathrm{ORF}$. To investigate the regulatory effects of the bifidobacterial promoter, regions of different gene promoters, P504, P572, and P919, were amplified with primer sets suitable for each (primer P504, P572 and P919, respectively) from genomic DNA of B. pseudocatenulatum SJ32, B. lactis SH5 and B. bifidum BGN4, respectively. The amplified putative promoter sequences were cloned into the $\mathrm{XbaI}$ and $\mathrm{KpnI}$ sites of $\mathrm{pB}-\mathrm{G} 1 \mathrm{ORF}$ to incorporate the promoter upstream from the $\beta$-galactosidase.

Successful cloning was confirmed by nucleotide sequencing. Each sub-cloned vector was introduced into $E$. coli via heat-shock and $\mathrm{CaCl}_{2}$ method and introduced into B. bifidum BGN4 by electroporation with the Gene Pulser Xcell Microbial Electroporation System (Bio-Rad, USA). The positive colonies were isolated, and the plasmids were purified and identified by restriction and sequence analyses.

\section{DNA Manipulation}

The chromosomal DNA of each bacterial strain used in this study was isolated with the MG Cell Genomic DNA Extraction SV Kit (MGmed, Korea). Plasmid DNA was extracted from Escherichia coli $\mathrm{DH} 5 \alpha$ transformant harboring pBES2 or each sub-cloned vector with a Plasmid Purification Mini Kit (Nucleogen, Korea) and methylated in vitro by GpC (M.CviPI) methyltransferase (Neb., USA). To identify the plasmid from the B. bifidum BGN4 transformants, plasmid DNA was extracted with a Plasmid Purification Mini Kit (Nucleogen) following an initial lysis step. Cells were resuspended in lysis buffer supplemented with lysozyme $(20 \mathrm{mg} / \mathrm{ml})$ and incubated at $37^{\circ} \mathrm{C}$ for $1 \mathrm{~h}$. The extracted DNA was identified by sequencing and comparing the restriction patterns with the original plasmid DNA derived from E. coli.

\section{Enzyme Preparation and Assay}

The incubated bacteria were centrifuged $(10,000 \times g$ for $3 \mathrm{~min}$ at $4^{\circ} \mathrm{C}$ ), and the harvested pellet was washed with $50 \mathrm{mM}$ sodium phosphate buffer ( $\mathrm{pH}$ 7.0). The washed cells were resuspended in the phosphate buffer ( $\mathrm{pH}$ 7.0) and disrupted with a sonicator (Q500; K-corporation, Korea) for $1.0 \mathrm{~s}$ with $1.0 \mathrm{~s}$ off intervals for $10 \mathrm{~min}$ in E. coli and $15 \mathrm{~min}$ in bifidobacteria. The disrupted bacterial solution was centrifuged at $10,000 \times g$ for $10 \mathrm{~min}$ at $4^{\circ} \mathrm{C}$, and the supernatant was used as a crude enzyme extract to assay the $\beta$-galactosidase activity.

The relative enzyme activity was measured by the release of paranitrophenol from para-nitrophenyl ( $\rho N P) \beta$-D-galactopyranoside (Sigma Aldrich). The crude enzyme extract $(80 \mu \mathrm{l})$ was added to $20 \mu \mathrm{l}$ of $5 \mathrm{mM} \rho \mathrm{NP} \beta$-D-galactopyranoside suspended in $50 \mathrm{mM}$ sodium phosphate buffer ( $\mathrm{pH}$ 7.0). The mixture was incubated at $37^{\circ} \mathrm{C}$, and the reaction was stopped by adding $100 \mu \mathrm{l}$ of $1 \mathrm{M}$ $\mathrm{Na}_{2} \mathrm{CO}_{3}$. The activity was measured in a 96-well microplate at $405 \mathrm{~nm}$ with a spectrophotometer (Model 680 Microplate reader; Bio-Rad). One unit (U) of enzyme activity was defined as the amount of enzyme that liberated $1 \mu \mathrm{mol}$ of $\rho \mathrm{NP}$ per minute at $37^{\circ} \mathrm{C}$ and $\mathrm{pH}$ 7.0. The volumetric activity (enzyme activity level relative to $\mathrm{ml}$ fermentation broth) was determined as units of $\beta$-galactosidase activity. The protein concentration was calculated according to the Bradford method [25]. 
Table 1. Bacterial strains and plasmids used in this study.

\begin{tabular}{|c|c|c|}
\hline Strains and plasmids & Description & Source or reference \\
\hline \multicolumn{3}{|l|}{ Bacterial strains } \\
\hline Bifidobacterium bifidum BGN4 & wild type; Transformation host; Original host of P919 & Isolated from breast-fed infant feces [63] \\
\hline B. longum RD47 & wild type; Original host of G1 & Isolated from breast-fed infant feces \\
\hline B. pseudocatenulatum SJ32 & wild type; Original host of P504 & Isolated from healthy human feces [64] \\
\hline B. lactis SH5 & wild type; Original host of P572 & Isolated from healthy human feces \\
\hline Escherichia coli $\mathrm{DH} 5 \alpha$ & $\begin{array}{l}\varphi 80 d l a c Z \Delta M 15 \Delta(\text { lacZY-argF)U169 deoR recA1 endA1 } \\
\text { hsdR17 }\left(r_{K}-m_{K}+\right) \text { sup E44 thi-1 gyrA96 relA1; Cloning host }\end{array}$ & Lab stock \\
\hline BGN4+pBES2 & B. bifidum BGN4 harboring pBES2 & This work \\
\hline BGN4+G1 & B. bifidum BGN4 harboring $\mathrm{pB}-\mathrm{G} 1$ & This work \\
\hline BGN4+P504G1 & B. bifidum BGN4 harboring pB-P504G1 & This work \\
\hline BGN4+P572G1 & B. bifidum BGN4 harboring pB-P572G1 & This work \\
\hline BGN4+P919G1 & B. bifidum BGN4 harboring pB-P919G1 & This work \\
\hline B. lactis AD011 & Lactic acid bacteria in our laboratory & Lab stock \\
\hline B. lactis RD68 & & Lab stock \\
\hline B. longum RD65 & & Lab stock \\
\hline B. bifidum КСТС 3418 & & Purchased from Korean Collection for Type Culture \\
\hline B. breve КСТС 3419 & & Purchased from Korean Collection for Type Culture \\
\hline B. longum RD72 & & Lab stock \\
\hline B. thermophilum KCCM 12097 & & Purchased from Korean Culture Center of Microorganisms \\
\hline B. bifidum КСТС 3440 & & Purchased from Korean Collection for Type Culture \\
\hline B. breve ATCC 15700 & & Purchased from American Type Culture Collection \\
\hline B. longum BORI & & Lab stock \\
\hline B. catenulatum КСТС 3221 & & Purchased from Korean Collection for Type Culture \\
\hline B. infantis KCTC 3249 & & Purchased from Korean Collection for Type Culture \\
\hline B. adolescentis ATCC 15703 & & Purchased from American Type Culture Collection \\
\hline B. breve КСТС 3220 & & Purchased from Korean Collection for Type Culture \\
\hline B. bifidum КСТС 3202 & & Purchased from Korean Collection for Type Culture \\
\hline B. longum RD03 & & Lab stock \\
\hline B. angulatum КСТС 3236 & & Purchased from Korean Collection for Type Culture \\
\hline B. pseudocatenulatum INT57 & & Lab stock \\
\hline B. animalis ATCC 25527 & & Purchased from American Type Culture Collection \\
\hline B. pseudocatenulatum G4 КСТС 3223 & & Purchased from Korean Collection for Type Culture \\
\hline Lactobacillus casei KFRI 699 & & Purchased from Korea Food Research Institute \\
\hline L. plantarum KFRI 708 & & Purchased from Korea Food Research Institute \\
\hline L. sakei KOK & & Lab stock \\
\hline L. delbrueckii bulgaricus КСТС 3635 & & Purchased from Korean Collection for Type Culture \\
\hline L. rhamnosus КСТС 3237 & & Purchased from Korean Collection for Type Culture \\
\hline L. acidophilus KCTC 3168 & & Purchased from Korean Collection for Type Culture \\
\hline Streptococcus thermophilus КСТС 3779 & & Purchased from Korean Collection for Type Culture \\
\hline Streptococcus thermophilus KCTC 5092 & & Purchased from Korean Collection for Type Culture \\
\hline Leuconostoc mesenteroides ATCC 27258 & & Purchased from American Type Culture Collection \\
\hline Lactococcus cremoris ATCC 19257 & & Purchased from American Type Culture Collection \\
\hline Lactococcus lactis KCTC 2013 & & Purchased from Korean Collection for Type Culture \\
\hline \multicolumn{3}{|l|}{ Plasmids } \\
\hline pBES2 & $7.6 \mathrm{kbp}, \mathrm{Ap}^{\mathrm{R}}, \mathrm{Cm}^{\mathrm{R}}$, Bifidobacterium - E. coli shuttle vector & [65] \\
\hline pB-G1 & $11 \mathrm{kbp}, \mathrm{pBES} 2$ derivate, containing PG1-G1 expression cassette & This work \\
\hline pB-G1ORF & $10.7 \mathrm{kbp}, \mathrm{pBES} 2$ derivate, containing G1ORF & This work \\
\hline pB-P504G1 & $11 \mathrm{kbp}$, pBES2 derivate, containing P504-G1 expression cassette & This work \\
\hline pB-P572G1 & 11.2 kbp, pBES2 derivate, containing P572-G1 expression cassette & This work \\
\hline pB-P919G1 & 10.9 kbp, pBES2 derivate, containing P919-G1 expression cassette & This work \\
\hline
\end{tabular}


Table 2. Primers for amplifying the $\beta$-galactosidase gene and putative promoters from Bifidobacterium.

\begin{tabular}{|c|c|c|c|c|}
\hline \multirow{2}{*}{$\begin{array}{c}\text { Primer } \\
\text { name }\end{array}$} & \multicolumn{2}{|c|}{ Sequences of primer } & \multirow{2}{*}{ Product } & \multirow{2}{*}{ Product information } \\
\hline & Forward $\left(5^{\prime} \rightarrow 3^{\prime}\right)$ & Reverse $\left(5^{\prime} \rightarrow 3^{\prime}\right)$ & & \\
\hline $\begin{array}{l}\text { primer } \\
\text { P504 }\end{array}$ & TtctagaGGGCGATTTTCTGCAGGGTT & GggatccACGTTCCTCTTTCGCATC & P504 & $\begin{array}{l}\text { A promoter of } \beta \text {-glucosidase } \\
\text { gene in SJ32 [36] }\end{array}$ \\
\hline $\begin{array}{l}\text { primer } \\
\text { P572 }\end{array}$ & TtctagaATGCTGCTCCTTATGTGTC & CggatccTGCTGATTCCTCCTGTCG & P572 & $\begin{array}{l}\text { A promoter of } \beta \text {-glucosidase } \\
\text { gene in } \mathrm{SH} 5 \text { [36] }\end{array}$ \\
\hline $\begin{array}{l}\text { primer } \\
\text { P919 }\end{array}$ & TtctagaTGAAGTGTGTCGTGTGGC & CggatccTGGTGTACCTTTTCTTGCTT & P919 & $\begin{array}{l}\text { A promoter of ribosomal } \\
\text { protein gene in BGN4 [37] }\end{array}$ \\
\hline $\begin{array}{l}\text { primer } \\
\text { G1ORF }\end{array}$ & TggatccATGGCCGAGAACACCTCG & CgaattcTCAGCTTAACGCCACAGC & G1ORF & A $\beta$-galactosidase gene in RD47 \\
\hline $\begin{array}{l}\text { primer } \\
\text { G1 }\end{array}$ & CGtctagaCСТTСТСССТTAАAТTTTTСТС & CcaattgTCAGCTTAACGCCACAGC & PG1+G1ORF & A $\beta$-galactosidase gene in RD47 \\
\hline
\end{tabular}

\section{Investigation on the Effects of Various Carbon Sources on $\beta$ - Galactosidase Expression}

To investigate the effects of various carbon sources on the expression of $\beta$-galactosidases, glucose, fructose, galactose, arabinose, cellobiose, maltose, sucrose, raffinose (all from Sigma Aldrich) or lactose (Trade TCI Mark, Japan) at a 2\% concentration was added into the MRS medium or MRS medium without glucose based on the fact that $2 \%$ glucose is generally included in MRS medium. Transformants and non-transformants were inoculated with these modified MRS media and incubated for $18 \mathrm{~h}$ at $37^{\circ} \mathrm{C}$. $\beta$-Galactosidase activities were assayed as described above.

\section{Plasmid Stability Test}

The stability of the plasmids constructed in this study was tested under non-selective conditions. Approximately $10^{2}$ bacteria were inoculated in $8 \mathrm{ml}$ of MRS and grown for $24 \mathrm{~h}$. In these growth conditions, the number of bacteria in the culture reached approximately $5.0 \times 10^{8}$ to $2.0 \times 10^{9} \mathrm{CFU} / \mathrm{ml}$, which corresponds to approximately 20 generations. The culture was diluted and inoculated in a new medium and cultured under the same conditions. After 100 generations, the plasmid stability was assessed by plating diluted aliquots on MRS agar medium with or without chloramphenicol and comparing colony counts on selective or non-selective MRS plates.

\section{Hydrolysis of Milk Lactose by Enzyme or Transformants}

Commercial milk from Seoul Milk (Seoul Dairy Cooperative, Korea) was heated to $95^{\circ} \mathrm{C}$ for $30 \mathrm{~min}$ for further sterilization and elimination of dissolved oxygen. For enzyme hydrolysis, crude enzyme extract $(50 \mu \mathrm{g})$ produced as described above was added to $1 \mathrm{ml}$ of sterile milk. The mixtures were incubated for $0,1,2,3,4,5$, 6,7 , or $8 \mathrm{~h}$ at $40^{\circ} \mathrm{C}$, which is the optimal temperature for the hydrolytic activity of G1. After the incubation, each mixture was boiled at $100^{\circ} \mathrm{C}$ for $5 \mathrm{~min}$ in order to inactivate the enzyme, and samples for HPLC were prepared as described by Marsili et al. [26]. For this, $1 \mathrm{ml}$ of water and $4 \mathrm{ml}$ of acetonitrile were added to each $1 \mathrm{ml}$ of sample and then shaken for $1 \mathrm{~min}$ and centrifuged to obtain a clear supernatant. The supernatant was filtered with a
$0.2 \mu \mathrm{m}, 13 \mathrm{~mm}$ PVDF Acrodisc syringe filter (Pall Corporation, USA). Then, $5 \mu$ l was injected for HPLC analysis.

Next, $5.0 \times 10^{8}$ CFU of RD47, BGN4, BGN4+pBES2 or BGN4+G1 were inoculated into $5 \mathrm{ml}$ of the prepared milk. Incubation was carried out at $37^{\circ} \mathrm{C}$, the optimum temperature for the bacterial growth, for $0,3,9,15,21,27,45,63$, or $93 \mathrm{~h}$. After the incubation, each mixture was boiled at $100^{\circ} \mathrm{C}$ for $5 \mathrm{~min}$ in order to inactivate the bacteria, and samples for HPLC were prepared as described above.

\section{HPLC}

Lactose concentrations were determined using the YL9100 HPLC System (Younglin, Korea) equipped with a YL9101 vacuum degasser, a YL9110 quaternary pump, a YL9131 column department, a 9170 RI detector, and a 9150 Autosampler.

A YMC-Pack Polyamine II, $250 \times 4.6 \mathrm{~mm}$ column (YMC, Korea) was used with $75 \%$ acetonitrile as mobile phase at a flow rate of $1 \mathrm{ml} / \mathrm{min}$. The column temperature was constant at $26^{\circ} \mathrm{C}$. Calibration was carried out with external standards calculated by sugar solutions, for which the concentration is known. Samples were analyzed in triplicate.

\section{Statistical Analysis of Data}

The results generated from this study except for Fig. 4 were subjected to one-way analysis of variance (ANOVA) test at a 5\% level of significance and post-hoc test (Duncan's multiple range test) using SigmaPlot 12 software. In the Fig. 4, results were compared using an paired, two-tailed $t$ test using SigmaPlot 12 software. Significant $p$ values for all comparisons are depicted in figure as follows: ${ }^{*} p<0.05,{ }^{* *} p<0.01$, and ${ }^{* * *} p<0.001$.

\section{Results}

\section{Gene Cloning and Heterologous Expression of $\beta$-Galactosidase from B. longum RD47}

To obtain $\beta$-galactosidase over-expressing bifidobacteria using a heterologous gene from closely related organisms, it was necessary to find a gene exhibiting strong $\beta$ - 
galactosidase activity derived from bifidobacteria. In the preliminary studies, Bifidobacterium longum RD47 showed the greatest level of $\beta$-galactosidase activity [23], and we also found three $\beta$-galactosidase genes (G1, G3, and G4) in the full genome of RD47, which were cloned and characterized for hydrolysis and transgalactosylation, respectively. Among them, G1 showed the highest hydrolysis and transgalactosylation activity, and we chose it as the gene for our experiment. The size of this gene is $3,072 \mathrm{bp}$, corresponding to 1,024 amino acids and a molecular mass of $112.64 \mathrm{kDa}$. The optimal $\mathrm{pH}$ and temperature for the hydrolytic activity of G1 were $\mathrm{pH} 8.5$ and $40^{\circ} \mathrm{C}$, respectively [24]. B. bifidum $\mathrm{BGN} 4$ was the transformation host in which G1 was expressed heterologously. BGN4, which originated from the feces of a breast-fed infant, has been used as a probiotic strain in global food markets because of its various benefits. BGN4 exhibits a remarkable colon cell binding ability [27, 28], improves immune function [29-33] and has anti-tumor effects [34]. In addition, BGN4 is a relatively genetically accessible strain among bifidobacteria and is therefore suitable for use in genetically engineered probiotics [35].

G1 was amplified from the genome of RD47 and subcloned into pBES2 with combinations of several bifidobacterial promoters (Table 2) including its own promoter and transformed into BGN4 as the host. The bifidobacterial promoters used in this study are listed in Table 2.

\section{Comparison of Hydrolytic Activities between Transformants and Non-Transformants}

Strong promoters are required for the expression of a target gene. In previous studies, the strengths of various bifidobacterial promoters were compared using glucosidase as a reporter gene in BGN4. Among them, P504, P572, and P919 originated from B. pseudocatenulatum SJ32, Bifidobacterium animalis subsp. lactis $\mathrm{SH} 5$ and B. bifidum BGN4, respectively, were relatively strong and constitutive [36, 37]. To develop bifidobacteria that strongly express $\beta$-galactosidase, we decided to use these promoters. G1 was expressed in BGN4 with combinations of P504, P572, P919 or its own promoter. The $\beta$-galactosidase activity of the recombinant bifidobacteria was determined using $\rho \mathrm{NPG}$ as the substrate to compare the strengths of the promoters. As a result, BGN4+G1, which is BGN4 in which G1 is expressed with the combination of its own promoter, exhibited the highest hydrolytic activity (Fig. 1). When the enzymatic activities of the cultures incubated for $18 \mathrm{~h}$ were compared, the $\beta$ galactosidase activity of BGN4+G1 was approximately 4 times higher than that of wild-type BGN4 and 6 times higher than that of wild-type RD47, the original host of G1 (Fig. 1A). The strength of the promoters was in the order of the G1 promoter followed by P572, P919, and P504 at $18 \mathrm{~h}$ incubation. However, when the incubation time was varied from $12 \mathrm{~h}-30 \mathrm{~h}$, the order of the other promoter strengths, except for the G1 promoter, was different (Fig. 1B). BGN4+G1 exhibited the highest hydrolytic activity regardless of the incubation time, for which the enzyme activity was continuously 2.5 to 4.2 times higher than that of BGN4. Many previous studies reported that the consensus sequences ( -35 and -10 regions) [38, 39], spacer sequences [39, 40], TG motif [41], UP elements [42] and the promoters' structural properties [43] can all affect the promoter
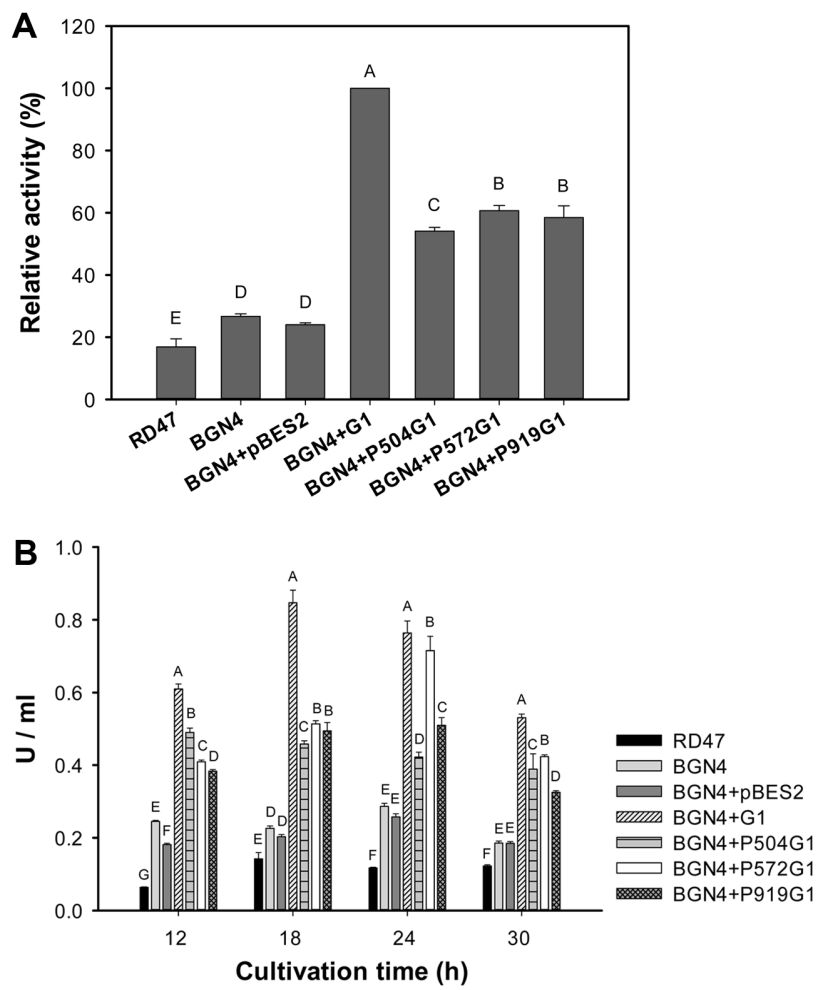

Fig. 1. Comparison of the $\beta$-galactosidase activities between the wild-type Bifidobacterium sp. and recombinant BGN4 with various vector constructs.

The bacteria were cultured at $37^{\circ} \mathrm{C}$ for 12 to $30 \mathrm{~h}$. (A) Shows the relative activities at $18 \mathrm{~h}$, and (B) shows the volumetric activities at incubation times from 12 to $30 \mathrm{~h}$. The $\beta$-galactosidase activity was determined at $37^{\circ} \mathrm{C}$ in $50 \mathrm{mM}$ phosphate buffer ( $\mathrm{pH}$ 7.0) with $\rho \mathrm{NPG}$ as the substrate. RD47, B. longum RD47; BGN4, B. bifidum BGN4; others, B. bifidum BGN4 harboring each vector. ANOVA analysis was done and statistically significant differences by Duncan's multiple range test $(p<0.05)$ were indicated by upper case alphabets. Experiments were repeated three times independently. 
strength. The promoters used in this study seem to differ in strength due to differences in those factors.

We next compared the enzymatic activities of the recombinants with 35 wild-type lactic acid bacteria in our laboratory including Bifidobacterium, Lactobacillus, Streptococcus, Leuconostoc and Lactococcus (Fig. 2). Enzyme activities of the recombinants were markedly superior to those of any other lactic acid bacteria used in this study. Incidentally, as already known, Bifidobacterium overall had a higher $\beta$ galactosidase activity than any other genera of lactic acid bacteria.

In a previous study, G1 was ligated into the pColdI Vector system (TAKARA) and expressed in E. coli BL21 [24]. When the $\mathrm{OD}_{600}$ of the recombinant E. coli reached 0.4 to 0.6 , the expression of the cloned gene was induced by adding $1 \mathrm{mM}$ isopropyl 1-thio- $\beta$-D-galactopyranoside (Tokyo Chemical Industry Co., Ltd., Japan). The recombinant E. coli was then cultured aerobically at $37^{\circ} \mathrm{C}$ for $21 \mathrm{~h}$, and the enzyme activity of G1 was the highest at this point. At the highest point of enzyme activity, the volumetric activity of the $\mathrm{G} 1$ recombinant E. coli was $0.46 \mathrm{U} / \mathrm{ml}$ fermentation broth, while BGN4+G1 was $0.85 \mathrm{U} / \mathrm{ml}$ fermentation broth, for which the G1 expression level of the recombinant bifidobacteria was approximately 2 times higher than that of the recombinant E. coli. The utilization of BGN4+G1 is expected to be high because BGN4+G1 exhibited a better enzymatic activity than any other lactic acid bacteria and the G1 recombinant E. coli using an overexpression vector.

\section{Effects of Carbon Sources on $\beta$-Galactosidase Expression}

The effects of various carbon sources, including glucose, arabinose, galactose, fructose, sucrose, lactose, maltose, cellobiose and raffinose, on the activities of $\beta$-galactosidase from G1 transformants are shown in Fig. 3.

Among all the glucose-free MRS media with various carbon sources added, $\beta$-galactosidase in transformants grown on lactose had the highest activity at $18 \mathrm{~h}$ at $37^{\circ} \mathrm{C}$ (Fig. 3). This result was compatible with the results of Hsu et al. [44, 45], who reported that lactose was an efficient inducer for the synthesis of $\beta$-galactosidase. The complete genome sequence of BGN4, which is the transformation host used in this study, has been determined (Accession No. NC_017999.1). According to the annotated gene information in this whole genome sequence, the lac operon exists in BGN4, and it suggests that the expression of $\beta$ galactosidases in BGN4 increases when lactose is the only carbon source [46]. This might be one of the most common causes for the highest $\beta$-galactosidase activity of the transformants when lactose was used as a carbon source except for glucose. At this point, we wondered if the

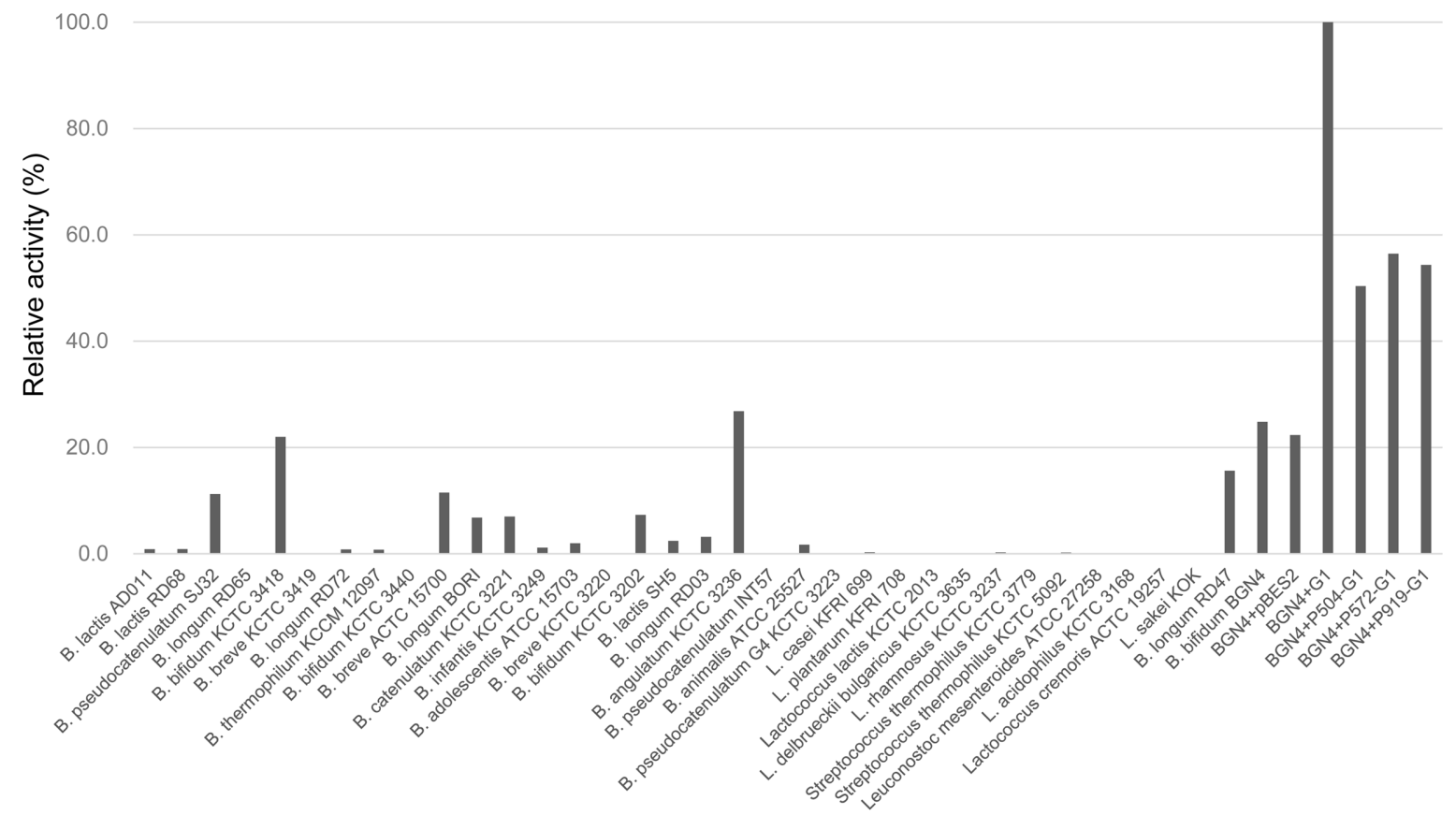

Fig. 2. Comparison of the $\beta$-galactosidase activities between 35 lactic acid bacterial strains and the recombinant BGN4.

The bacteria were cultured at $37^{\circ} \mathrm{C}$ for $18 \mathrm{~h}$. The $\beta$-galactosidase activity was determined at $37^{\circ} \mathrm{C}$ in $50 \mathrm{mM}$ phosphate buffer (pH 7.0) with $\rho$ NPG as the substrate. Experiments were repeated three times independently. 

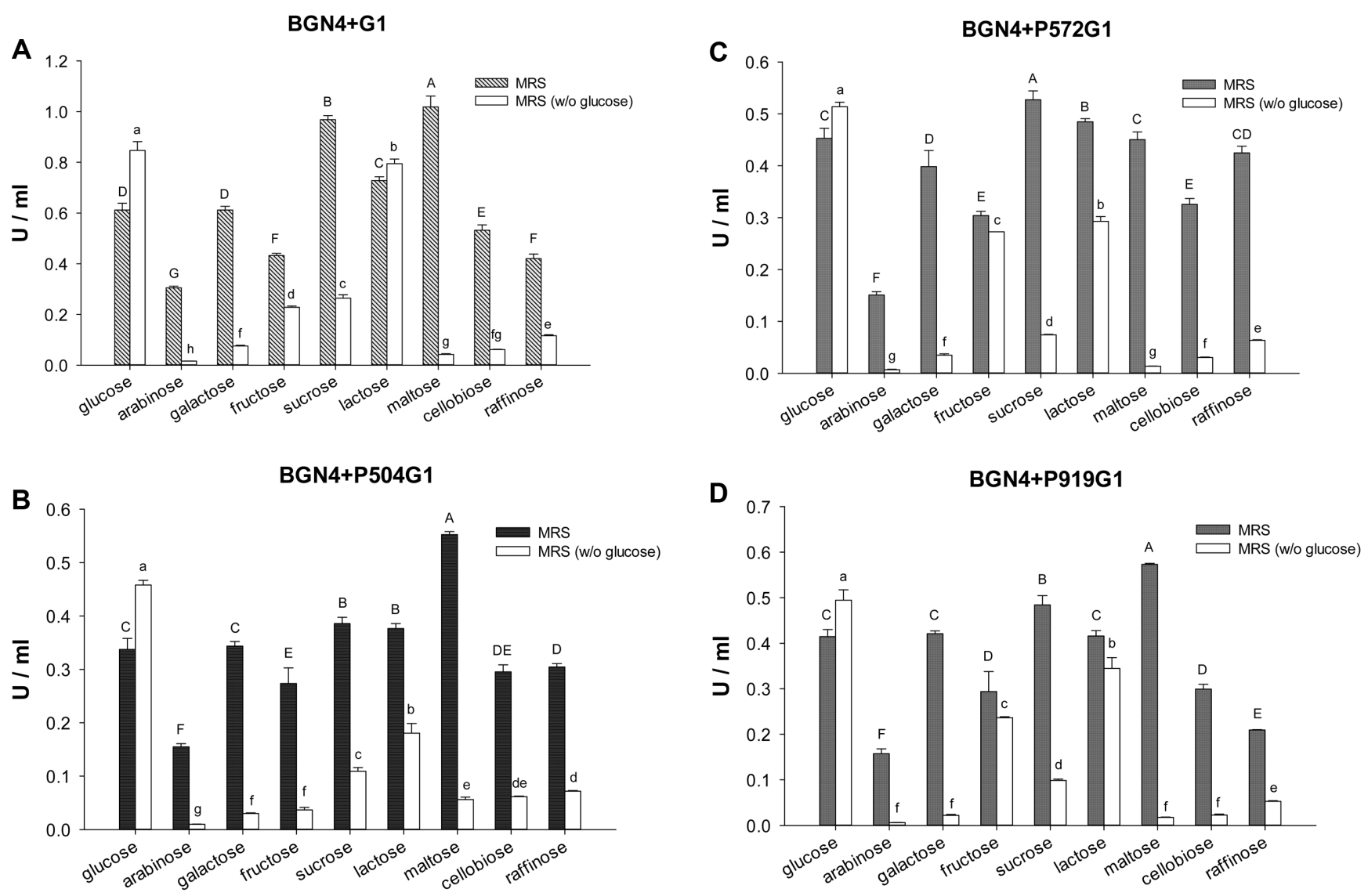

Fig. 3. Effects of the carbon sources on the production of $\beta$-galactosidase in the recombinant BGN4.

The bacteria were cultured at $37^{\circ} \mathrm{C}$ for $18 \mathrm{~h}$, and the $\beta$-galactosidase activity was determined at $37^{\circ} \mathrm{C}$ in $50 \mathrm{mM}$ phosphate buffer (pH 7.0) with $\rho$ NPG as the substrate. ANOVA analysis was done independently for the results from the MRS and the results from the MRS without glucose. For the results from the MRS, statistically significant differences by Duncan's multiple range test $(p<0.05)$ were indicated by upper case alphabets, and for the results from the MRS without glucose, these were indicated by lower case alphabets. Experiments were repeated three times independently.

increased $\beta$-galactosidase activity of the BGN4 transformants in the presence of lactose was completely due to the lac operon in the BGN4 and not G1. When the $\beta$-galactosidase activity of the wild-type BGN4 was subtracted from that of the G1 transformants, the enzyme activity of G1 alone could be obtained. The enzyme activity of G1 under lactose was at least 3 times more induced compared with the enzyme activity of G1 under other sugars used in this study except for glucose (data not shown). It means that not only the $\beta$ galactosidases of the BGN4 itself but also the heterologously expressed G1 was induced by lactose. Notably, BGN4+G1 and BGN4+P919G1 only exhibited such a phenomenon while the other transformants did not. Because the only difference between the former and latter was the promoter located upstream of G1, it seemed that G1 itself did not react to lactose but rather that the promoter was responding. Because G1 is a $\beta$-galactosidase gene, it is reasonable that the G1 promoter is induced by lactose. However, P919 is a promoter for the ribosomal protein gene [37], and it is not understood why it reacts to lactose; thus, further study is needed. Among all the promoters used in the experiment, the G1 promoter was the most strongly induced under lactose based on the enzyme activity of G1.

In general, when the various carbon sources were added to the MRS medium containing glucose, the $\beta$-galactosidase activity tended to be much higher than that when the various carbon sources were added to the MRS medium without glucose (Fig. 3). The case of BGN4+G1 under lactose was exceptional because the G1 promoter reacted strongly to lactose (Fig. 3A). However, when $2 \%$ glucose was added to the MRS medium containing glucose to yield a total of $4 \%$ glucose, the enzyme activity was lower than that when $2 \%$ glucose was added to the glucose-free MRS, which was consistent with previous studies showing that 
glucose at a high concentration inhibited $\beta$-galactosidase expression [23, 46-49]. This phenomenon is known as carbon catabolite repression. In bacteria, the phosphotransferase system (PTS) [46, 47, 50] and catabolite repressor/activator (Cra) model [51] have been identified as mechanisms of carbon catabolite repression. Glucose is transported into the cell by PTS, which controls the cytoplasmic cAMP concentrations. Because cAMP-CAP complexes are required for the transcription of promoters which regulate the expression of genes required for use of alternative carbon sources, cAMP control by the activities of PTS regulates the expression of genes related to the utilization of alternative carbon sources [47]. On the other side, the Cra protein, either a repressor or activator of gene transcription by interacting with the RNA polymerase binding site, binds to the catabolites of glycolytic substrates, and these complexes are unable to bind to the DNA associated with the RNA polymerase binding site resulting in the catabolite repression effect [51]. A high glucose concentration seems to lower the activity of $\beta$-galactosidase by these mechanisms.

In all the transformants except for BGN4+P572G1, when $2 \%$ maltose was added to the MRS medium with glucose, the biosynthesis of $\beta$-galactosidase was highly induced compared to when glucose alone was used as a carbon source. On the other hand, BGN4+P572G1 had the highest enzymatic activity under the addition of $2 \%$ sucrose. These results were in contradiction to the results showing that when maltose or sucrose was used as the only carbon source, $\beta$-galactosidase was not induced much (Fig. 3). Presumably, sucrose and maltose are synergistic in $\beta$-gal expression when glucose is present.

\section{Effects of Non-Selective Conditions on $\beta$-Galactosidase Expression}

The experiments from here on were conducted for BGN4+G1 because it exhibited the greatest $\beta$-galactosidase activity among all the G1 recombinants. We next investigated the $\beta$-galactosidase expression of the G1 recombinant under non-selective conditions. The BGN4+G1 recombinant was inoculated with MRS medium in the absence of antibiotics and incubated up to $60 \mathrm{~h}$ at $37^{\circ} \mathrm{C}$. Up until the incubation time reached $60 \mathrm{~h}$, the $\beta$-galactosidase activity of BGN4+G1 did not decrease in the absence of selection pressure; however, at most points, it was rather slightly higher than when antibiotics were present in the medium (Fig. 4).

\section{Plasmid Stability under Non-Selective Conditions}

In order to estimate the stability of pB-G1, a pBES2 derivate containing the PG1-G1 expression cassette in
BGN4, the strain was grown in MRS broth without antibiotics. After 100 generations, culture aliquots were plated on MRS agar with or without antibiotics [52]. The presence of $\mathrm{pB}-\mathrm{G} 1$ in the BGN4 colonies under the nonselective conditions was identified by comparing the restriction patterns with the original plasmid DNA. As a result, the number of transformants under nonselective conditions was maintained at $100 \%$ until 60 generations and thereafter, rapidly decreased and finally decreased by $53 \%$ after 100 generations compared with the selective conditions. However, it was maintained consistently above a high bacterial count of $5.0 \times 10^{8} \mathrm{CFU} / \mathrm{ml}$ for the entire 100 generations.

For engineered bacteria, heterologous expression adds an unnatural load, which can challenge host cells with a significant burden [53-55]. This metabolic burden can result in a decline of the biomass yield, cellular viability, recombinant protein productivity and plasmid stability [56]. As bacterial generations proceed, the segregational instability of the plasmid appears to have a greater impact on the process productivity than on the structural stability, especially at higher frequencies under non-selective conditions, and the formation and accumulation of a plasmid-free population reduces the final plasmid DNA yields [57]. According to our results in this study, in the absence of antibiotics, the bacterial counts for the BGN4+G1 transformant were kept above $5.0 \times 10^{8} \mathrm{CFU} / \mathrm{ml}$

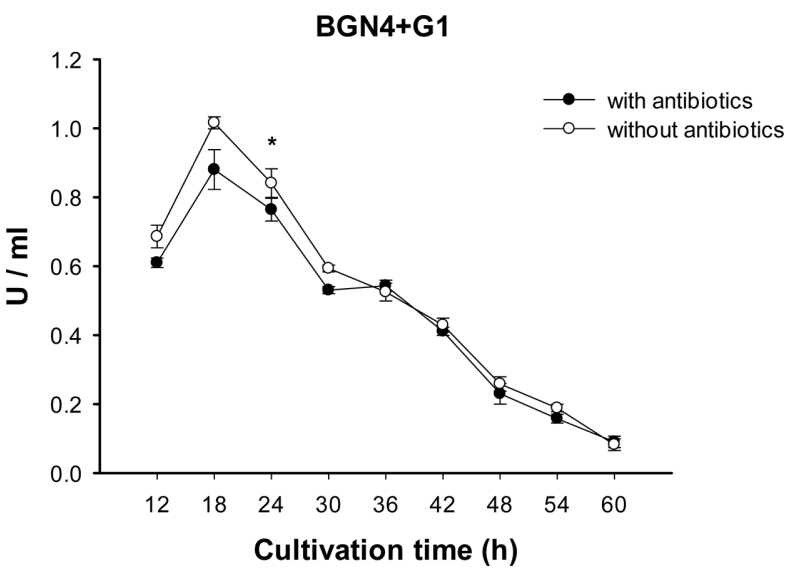

Fig. 4. Effects of non-selective conditions on $\beta$-galactosidase expression from the recombinant bifidobacteria.

BGN4+G1 was cultured at $37^{\circ} \mathrm{C}$ up to $60 \mathrm{~h}$ in MRS medium with or without chloramphenicol. The $\beta$-galactosidase activity was determined at $37^{\circ} \mathrm{C}$ in $50 \mathrm{mM}$ phosphate buffer (pH 7.0) with $\rho \mathrm{NPG}$ as the substrate. An paired, two-tailed $t$ test was done and significant $p$ values for all comparisons are depicted in figure as follows: ${ }^{*} p<0.05,{ }^{* *} p<0.01$, and ${ }^{* * *} p<0.001$. Experiments were repeated three times independently. 
for 100 generations, and the enzyme activity did not decrease for $60 \mathrm{~h}$ compared with the selective conditions. It is believed that the stability of the subcloned plasmid DNA and the recombinant protein expression will promote the use of the BGN4+G1 transformant and pB-G1 plasmid in industry or further laboratory studies.

\section{Lactose Hydrolysis}

Lactose hydrolysis experiments were carried out with BGN4+G1, BGN4, BGN4 containing pBES2 (BGN4+pBES2), which is the Bifidobacterium-E. coli shuttle vector used for the G1 subcloning, and RD47 by reacting them with milk and by reacting their crude enzyme extracts with milk. The lactose hydrolysis capacity in milk was determined by measuring the residual lactose in the milk by HPLC.

After inoculating $5.0 \times 10^{8} \mathrm{CFU}$ of each bacteria into $5 \mathrm{ml}$ of milk, the amount of residual lactose in the milk was measured for 0-93 h, and the result is shown in Fig. 5A. BGN4+G1 consumed the most lactose in the milk within the same time period, followed by BGN4 and RD47. This is consistent with the order of $\beta$-galactosidase activity in each bacteria (Fig. 1). It was reported that only about $30 \%$ of the lactose is removed from fermented milk products [58], and in reality, BGN4 and RD47 eliminated only $17 \%$ and $35 \%$ of the lactose in the milk at $93 \mathrm{~h}$, respectively. However, BGN4+G1 removed $50 \%$ of the lactose in the milk by $63 \mathrm{~h}$ and a final $61 \%$ at $93 \mathrm{~h}$. This is about twice the lactose removal rate of conventional fermented milk products.

After inoculating $50 \mu \mathrm{g}$ of protein as a crude enzyme extract from each bacteria into $1 \mathrm{ml}$ of milk, the amount of residual lactose in the milk was measured up to $8 \mathrm{~h}$ (Fig. 5B). The $\beta$-galactosidase of BGN4+G1 consumed the most lactose in the milk within the same time period followed by that of RD47 and BGN4. This order is consistent with the order for the volumetric activity in the crude enzyme extract of each bacteria. The volumetric activities of $\beta$-galactosidase in $50 \mu \mathrm{g}$ of protein for RD47, BGN4, BGN4+pBES2 and BGN4+G1 were 0.087, 0.053, 0.041 , and $0.166 \mathrm{U} / \mathrm{ml}$, respectively. The $\beta$-galactosidase of BGN4+G1 hydrolyzed $51 \%$ of the lactose in the milk at $2 \mathrm{~h}$, but after that, the enzyme activity sharply decreased, and the lactose in the milk was slowly decomposed and only $60 \%$ was hydrolyzed at $8 \mathrm{~h}$.

\section{Discussion}

In this study, we developed a $\beta$-galactosidase overexpressing bifidobacteria strain by using a heterologous gene from B. longum RD47 which is one of the bifidobacterial
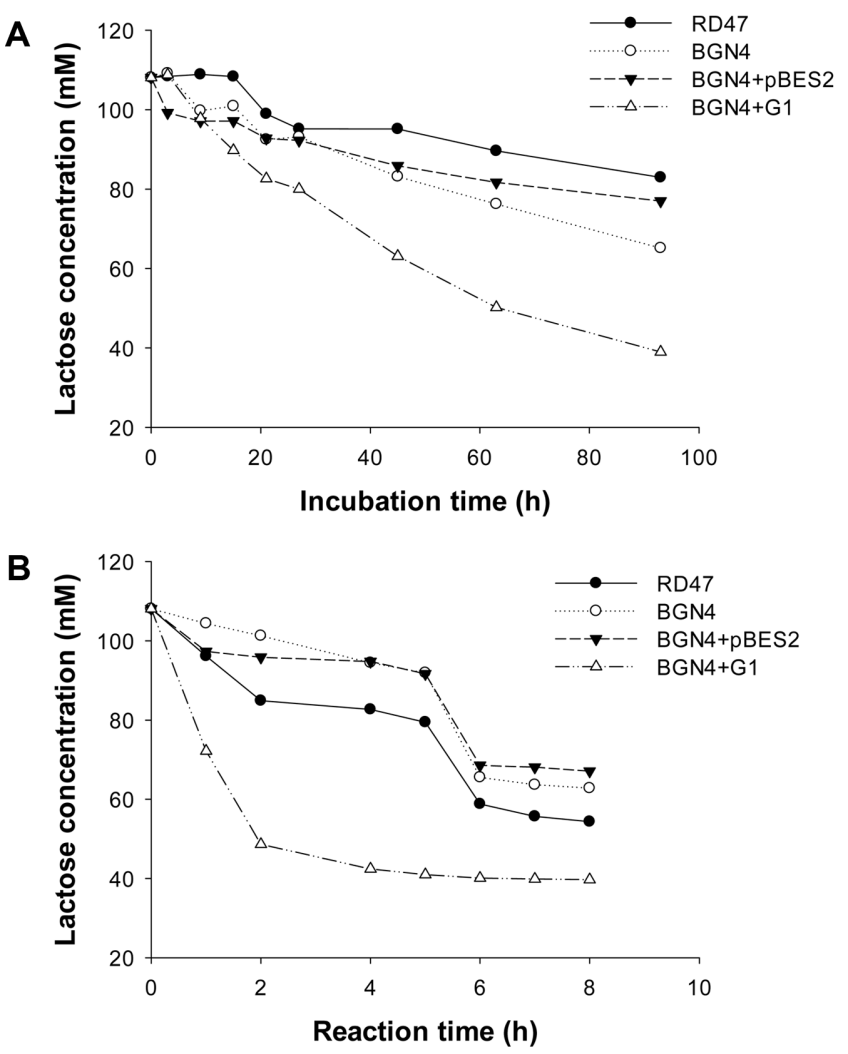

Fig. 5. Lactose hydrolysis in milk by bacteria or $\beta$-galactosidase. After reacting the milk and bacteria at $37^{\circ} \mathrm{C}(\mathrm{A})$ or the milk and $\beta$ galactosidase of the crude enzyme extract at $40^{\circ} \mathrm{C}(\mathrm{B})$ for a certain period of time, residual lactose was measured by HPLC. RD47, $B$. longum RD47; BGN4, B. bifidum BGN4; others, B. bifidum BGN4 harboring each vector.

strains with the greatest level of $\beta$-galactosidase activity. Among the recombinant bifidobacteria, BGN4+G1 has the highest $\beta$-galactosidase activity, for which the hydrolytic activity was continuously 2.5 to 4.2 times higher than that of BGN4 and 4.3 to 9.6 times higher than that of the wildtype RD47 (Fig. 1B). The $\beta$-galactosidase level of BGN4+G1 was remarkably superior to that of any of the other 35 lactic acid bacteria used in this study (Fig. 2). Furthermore, at the time when the enzyme activity was the highest, the volumetric activity of BGN4+G1 was $0.85 \mathrm{U} / \mathrm{ml}$ fermentation broth, which was twice as high as that of the G1 recombinant $E$. coli using an overexpression vector. In this regard, industrial or research utilization of BGN4 + G1 is expected to be high.

It has been generally reported that only about $30 \%$ of the lactose is removed from conventional fermented milk products [58,59], and in agreement with this, BGN4, which has the second highest $\beta$-galactosidase activity among the 
35 lactic acid bacteria in our laboratory, only eliminated $35 \%$ of lactose in milk. Lactose intolerant subjects will have typical clinical symptoms such as diarrhea, flatulence and bloating when they consume these products. To prevent this, when making fermented milk, fermentation by a starter and the reaction with $\beta$-galactosidase sometimes proceed together [60]. However, BGN4+G1 solely hydrolyzed $50 \%$ of the lactose in milk at $63 \mathrm{~h}$ and finally $61 \%$ at $93 \mathrm{~h}$ during fermentation (Fig. 5A). This suggests that it is necessary to improve the $\beta$-galactosidase activity of the starter strains by expressing an exogenous enzyme or by mutation in order to reduce the residual lactose content of fermented milk for lactose intolerant consumers. From our results, the G1 expression cassette used to construct $\mathrm{BGN} 4+\mathrm{G} 1$ can be used to increase the $\beta$ galactosidase activity of starter strains using a food-grade vector or CRISPR technology because of the safety of the genetic origin and the strong intensity of the gene expression.

Currently, in the production of lactose-free milk, $\beta$ galactosidase is mainly used, and the process is carried out only in such a way that a soluble enzyme is added without using the enzyme-immobilization method due to problems with the microbial stability of the final product [60]. Although BGN4+G1 does not have a higher enzyme activity than some recombinant strains in other studies [2, $61,62]$, it has an advantage in that it is safe because the bacterial host and gene are derived from bifidobacteria, the GRAS bacteria, and the $\beta$-galactosidase activity is remarkably high compared with the other 35 lactic acid bacteria. Furthermore, the $\beta$-galactosidase of BGN4+G1 hydrolyzed half of the lactose in whole milk in $2 \mathrm{~h}$ using a crude enzyme extract with $50 \mu \mathrm{g}$ of protein (Fig. 5B), and it is expected to have a greater effect if the amount of crude enzyme extract used for the reaction is increased. It is believed that the purification of G1 from BGN4 by attaching a his-tag to the gene will have industrial significance, such as in the production of lactose-free milk or fermented milk.

Currently, we are verifying the effect of the $\beta$-galactosidase activity of bifidobacteria on LI alleviation by administering $\beta$-galactosidase-reduced, wild-type, and $\beta$-galactosidase over-expressing bifidobacteria to post-weaning Balb/c mice. We intend to use BGN4+G1 as a $\beta$-galactosidase overexpressing bifidobacteria strain in the above experiment, and this is the main purpose of developing the bifidobacteria that highly express $\beta$-galactosidase in this study. If the BGN4+G1 exhibits a significant effect on LI alleviation, it is expected that BGN4+G1 can be reproduced by using a food-grade vector for bifidobacteria, and it will be utilized as an LI treatment strain.
Incidentally, in this study we also provided information on using strong bifidobacterial promoters shown in previous studies by comparing the strengths and characteristics of the enzymatic activity of these promoters.

\section{Acknowledgments}

This work was carried out with support from the National Research Foundation of Korea (NRF) grant (No. 2017R1A2B2012390) funded by the Korea government (MSIP), High Value-added Food Technology Development Program (No. 317043-3), Korea Institute of Planning and Evaluation for Technology in Food, Agriculture, Forestry and Fisheries (IPET), Ministry of Agriculture, Food and Rural Affairs (MAFRA), and the Bio \& Medical Technology Development Program of the National Research Foundation (NRF) funded by the Ministry of Science, ICT \& Future Planning (NRF-2017M3A9F3041747).

\section{Conflict of Interest}

The authors have no financial conflicts of interest to declare.

\section{References}

1. Nguyen T-T, Nguyen H-M, Geiger B, Mathiesen G, Eijsink VG, Peterbauer CK. 2015. Heterologous expression of a recombinant lactobacillal $\beta$-galactosidase in Lactobacillus plantarum: effect of different parameters on the sakacin Pbased expression system. Microb. Cell Fact. 14: 30.

2. Yuan T, Yang P, Wang Y, Meng K, Luo H, Zhang W. 2008. Heterologous expression of a gene encoding a thermostable $\beta$-galactosidase from Alicyclobacillus acidocaldarius. Biotechnol. Lett. 30: 343-348.

3. Kamran A, Bibi Z, Aman A, Qader SAU. 2016. Lactose hydrolysis approach: isolation and production of $\beta$ galactosidase from newly isolated Bacillus strain B-2. Biocatal. Agric. Biotechnol. 5: 99-103.

4. Nguyen TH, Splechtna B, Steinböck M, Kneifel W, Lettner HP, Kulbe KD. 2006. Purification and characterization of two novel $\beta$-galactosidases from Lactobacillus reuteri. J. Agric. Food Chem. 54: 4989-4998.

5. Splechtna B, Nguyen TH, Zehetner R, Lettner HP, Lorenz W, Haltrich D. 2007. Process development for the production of prebiotic galacto-oligosaccharides from lactose using $\beta$ galactosidase from Lactobacillus sp. Biotechnol. J. 2: 480-485.

6. Sani R, Chakraborti S, Sobti R, Patnaik P, Banerjee U. 1999. Characterization and some reaction-engineering aspects of thermostable extracellular $\beta$-galactosidase from a new Bacillus species. Folia Microbiol. 44: 367. 
7. Gänzle MG, Haase G, Jelen P. 2008. Lactose: crystallization, hydrolysis and value-added derivatives. Int. Dairy J. 18: 685694.

8. Nguyen T-T, Nguyen HA, Arreola SL, Mlynek G, Djinovic'Carugo K, Mathiesen G. 2012. Homodimeric $\beta$-galactosidase from Lactobacillus delbrueckii subsp. bulgaricus DSM 20081: expression in Lactobacillus plantarum and biochemical characterization. J. Agric. Food Chem. 60: 1713-1721.

9. Møller PL, Jørgensen F, Hansen OC, Madsen SM, Stougaard P. 2001. Intra-and extracellular $\beta$-galactosidases from Bifidobacterium bifidum and B. infantis: molecular cloning, heterologous expression, and comparative characterization. Appl. Environ. Microbiol. 67: 2276-2283.

10. Hsu CA, Lee SL, Chou CC. 2007. Enzymatic production of galactooligosaccharides by $\beta$-galactosidase from Bifidobacterium longum BCRC 15708. J. Agric. Food Chem. 55: 2225-2230.

11. Chanalia P, Gandhi D, Attri P, Dhanda S. 2018. Purification and characterization of $\beta$-galactosidase from probiotic Pediococcus acidilactici and its use in milk lactose hydrolysis and galactooligosaccharide synthesis. Bioorg. Chem. 77: 176-189.

12. Lewis ZT, Shani G, Masarweh CF, Popovic M, Frese SA, Sela DA. 2016. Validating bifidobacterial species and subspecies identity in commercial probiotic products. Pediatr. Res. 79: 445.

13. Tissier H. 1900. Recherchers sur la Flora Intestinale Normale et Pathologique du Nourisson. University of Paris. Thesis:1-253

14. Milani C, Lugli GA, Duranti S, Turroni F, Mancabelli L, Ferrario C. 2015. Bifidobacteria exhibit social behavior through carbohydrate resource sharing in the gut. Sci. Rep. 5: 15782.

15. Koropatkin NM, Cameron EA, Martens EC. 2012. How glycan metabolism shapes the human gut microbiota. Nat. Rev. Microbiol. 10: 323.

16. Rivière A, Selak M, Lantin D, Leroy F, De Vuyst L. 2016. Bifidobacteria and butyrate-producing colon bacteria: importance and strategies for their stimulation in the human gut. Front. Microbiol. 7: 979.

17. Turroni F, Milani C, Duranti S, Ferrario C, Lugli GA, Mancabelli L. 2018. Bifidobacteria and the infant gut: an example of co-evolution and natural selection. Cell. Mol. Life Sci. 75: 103-118.

18. James K, Motherway MOC, Bottacini F, Van Sinderen D. 2016. Bifidobacterium breve UCC2003 metabolises the human milk oligosaccharides lacto-N-tetraose and lacto-N-neotetraose through overlapping, yet distinct pathways. Sci. Rep. 6: 38560.

19. O'Connell Motherway M, Kinsella M, Fitzgerald GF, van Sinderen D. 2013. Transcriptional and functional characterization of genetic elements involved in galacto-oligosaccharide utilization by Bifidobacterium breve UCC 2003. Microb. Biotechnol. 6: 67-79.

20. Roy D, Berger JL, Reuter G. 1994. Characterization of dairyrelated Bifidobacterium spp. based on their $\beta$-galactosidase electrophoretic patterns. Int. J. Food Microbiol. 23: 55-70.
21. Smart JB, Pillidge CJ, Garman JH. 1993. Growth of lactic acid bacteria and bifidobacteria on lactose and lactoserelated mono-, di-and trisaccharides and correlation with distribution of $\beta$-galactosidase and phospho- $\beta$-galactosidase. J. Dairy Res. 60: 557-568.

22. Van Laere KM, Abee T, Schols HA, Beldman G, Voragen AG. 2000. Characterization of a Novel $\beta$-Galactosidase from Bifidobacterium adolescentis DSM 20083 Active towards Transgalactooligosaccharides. Appl. Environ. Microbiol. 66: 1379-1384.

23. Han YR, Youn SY, Ji GE, Park MS. 2014. Production of $\alpha$ and $\beta$-galactosidases from Bifidobacterium longum subsp. longum RD47. J. Microbiol. Biotechnol. 24: 675-682.

24. Oh SY, Youn SY, Park MS, Kim HG, Baek NI, Li Z. 2017. Synthesis of $\beta$-galactooligosaccharide using bifidobacterial $\beta$-galactosidase purified from recombinant Escherichia coli. J. Microbiol. Biotechnol. 27: 1392-1400.

25. Bradford MM. 1976. A rapid and sensitive method for the quantitation of microgram quantities of protein utilizing the principle of protein-dye binding. Anal. Biochem. 72: 248-254.

26. Marsili R, Ostapenko H, Simmons R, Green D. 1981. High performance liquid chromatographic determination of organic acids in dairy products. J. Food Sci. 46: 52-57.

27. Kim IH, Park MS, Ji GE. 2003. Characterization of adhesion of Bifidobacterium sp. BGN4 to human enterocyte-like Caco-2 cells. J. Microbiol. Biotechnol. 13: 276-281.

28. Ku S, You HJ, Ji GE. 2009. Enhancement of anti-tumorigenic polysaccharide production, adhesion, and branch formation of Bifidobacterium bifidum BGN4 by phytic acid. Food Sci. Biotechnol. 18: 749-754.

29. Lee MJ, Zang Z, Choi EY, Shin HK, Ji GE. 2002. Cytoskeleton reorganization and cytokine production of macrophages by bifidobacterial cells and cell-free extracts. J. Microbiol. Biotechnol. 12: 398-405.

30. Kim N, Ji GE. 2006. Modulatory activity of Bifidobacterium sp. BGN4 cell fractions on immune cells. J. Microbiol. Biotechnol. 16: 584-589.

31. Lee S, Koo N, Oh S. 2006. Regulatory effect on specific ige response of Bifidobacterium Bifidum (bgn4 Strain) in murine model of peanut allergy. J. Allergy Clin. Immunol. 117(2).

32. Kim N, Kunisawa J, Kweon MN, Eog Ji GE, Kiyono H. 2007. Oral feeding of Bifidobacterium bifidum (BGN4) prevents CD4(+) CD45RB(high) T cell-mediated inflammatory bowel disease by inhibition of disordered $\mathrm{T}$ cell activation. Clin. Immunol. 123: 30-39.

33. Hong KS, Kang HW, Im JP, Ji GE, Kim SG, Jung HC. 2009. Effect of probiotics on symptoms in Korean adults with irritable bowel syndrome. Gut Liver. 3: 101-107.

34. You HJ, Oh DK, Ji GE. 2004. Anticancerogenic effect of a novel chiroinositol-containing polysaccharide from Bifidobacterium bifidum BGN4. FEMS Microbiol. Lett. 240: 131-136.

35. Park MJ, Park MS, Ji GE. 2018. Improvement of electroporationmediated transformation efficiency for a Bifidobacterium 
strain to a reproducibly high level. J. Microbiol. Methods. 159: 112-119.

36. Youn SY, Park MS, Ji GE. 2012. Identification of the $\beta$ glucosidase gene from Bifidobacterium animalis subsp. lactis and its expression in B. bifidum BGN4. J. Microbiol. Biotechnol. 22: $1714-1723$

37. Wang Y, Kim JY, Park MS, Ji GE. 2012. Novel Bifidobacterium promoters selected through microarray analysis lead to constitutive high-level gene expression. J. Microbiol. 50: 638643.

38. McCracken A, Turner MS, Giffard P, Hafner LM, Timms P. 2000. Analysis of promoter sequences from Lactobacillus and Lactococcus and their activity in several Lactobacillus species. Arch. Microbiol. 173: 383-389.

39. Li J, Zhang Y. 2014. Relationship between promoter sequence and its strength in gene expression. Eur. Phys. J. E. Soft Matter 37(9): 44 .

40. Jensen PR, Hammer K. 1998. The sequence of spacers between the consensus sequences modulates the strength of prokaryotic promoters. Appl. Environ. Microbiol. 64: 82-87.

41. Helmann JD. 1995. Compilation and analysus of Bacillus Subtilis $\sigma$ A-dependent promoter sequences: evidence for extended contact between RNA polymerse and upstream promoter DNA. Nucleic Acids Res. 23: 2351-2360.

42. Estrem ST, Gaal T, Ross W, Gourse RL. 1998. Identification of an UP element consensus sequence for bacterial promoters. Proc. Natl. Acad. Sci. USA 95: 9761-9766.

43. Kumar A, Bansal M. 2018. Modulation of Gene Expression by Gene Architecture and Promoter Structure. IntechOpen 76051: 37-53.

44. Hsu C, Yu R, Chou C. 2005. Production of $\beta$-galactosidase by Bifidobacteria as influenced by various culture conditions. Int. J. Food Microbiol. 104: 197-206.

45. Hsu CA, Yu RC, Chou CC. 2006. Purification and characterization of a sodium-stimulated $\beta$-galactosidase from Bifidobacterium longum CCRC 15708. World J. Microbiol. Biotechnol. 22: 355-361.

46. Bidart GN, Rodríguez-Díaz J, Pérez-Martínez G, Yebra MJ. 2018. The lactose operon from Lactobacillus casei is involved in the transport and metabolism of the human milk oligosaccharide core-2 n-acetyllactosamine. Sci. Rep. 8: 7152.

47. Chan V, Dreolini LF, Flintoff KA, Lloyd SJ, Mattenley AA. 2002. The effects of glycerol, glucose, galactose, lactose and glucose with galactose on the induction of $\beta$-galactosidase in Escherichia coli. J. Exp. Microbiol. Immunol. 2: 130-137.

48. Ilyés H, Fekete E, Karaffa L, Fekete É, Sándor E, Szentirmai A. 2004. CreA-mediated carbon catabolite repression of $\beta$ galactosidase formation in Aspergillus nidulans is growth rate dependent. FEMS Microbiol. Lett. 235: 147-151.

49. Inchaurrondo V, Flores M, Voget C. 1998. Growth and $\beta$ galactosidase synthesis in aerobic chemostat cultures of Kluyveromyces lactis. J. Ind. Microbiol. Biotechnol. 20: 291-298.
50. Ullmann A. 1996. Catabolite repression: a story without end. Res. Microbiol. 147: 455-458.

51. Saier Jr MH, Ramseier TM. 1996. The catabolite repressor/ activator (Cra) protein of enteric bacteria. J. Bacteriol. 178: 3411-3417.

52. Gory L, Montel MC, Zagorec M. 2001. Use of green fluorescent protein to monitor Lactobacillus sakei in fermented meat products. FEMS Microbiol. Lett. 194: 127-133.

53. Ceroni F, Algar R, Stan GB, Ellis T. 2015. Quantifying cellular capacity identifies gene expression designs with reduced burden. Nat. Methods. 12: 415-418.

54. Silva F, Queiroz JA, Domingues FC. 2012. Evaluating metabolic stress and plasmid stability in plasmid DNA production by Escherichia coli. Biotechnol. Adv. 30: 691-708.

55. Ceroni F, Boo A, Furini S, Gorochowski TE, Borkowski O, Ladak YN. 2018. Burden-driven feedback control of gene expression. Nat. Methods. 15: 387-393.

56. Carneiro S, Ferreira EC, Rocha I. 2013. Metabolic responses to recombinant bioprocesses in Escherichia coli. J. Biotechnol. 164: 396-408.

57. Oliveira PH, Prazeres DM, Monteiro GA. 2009. Deletion formation mutations in plasmid expression vectors are unfavored by runaway amplification conditions and differentially selected under kanamycin stress. J. Biotechnol. 143: 231-238.

58. Harju M, Kallioinen H, Tossavainen O. 2012. Lactose hydrolysis and other conversions in dairy products: Technological aspects. Int. Dairy J. 22: 104-109.

59. Ohlsson JA, Johansson M, Hansson H, Abrahamson A, Byberg L, Smedman A. 2017. Lactose, glucose and galactose content in milk, fermented milk and lactose-free milk products. Int. Dairy J. 73: 151-154.

60. Dekker PJ, Koenders D, Bruins MJ. 2019. Lactose-free dairy products: market developments, production, nutrition and health benefits. Nutrients 11(3). pii: 551.

61. Becerra M, Prado SD, Cerdán E, Siso MG. 2001. Heterologous Kluyveromyces lactis $\beta$-galactosidase secretion by Saccharomyces cerevisiae super-secreting mutants. Biotechnol. Lett. 23: 33-40.

62. Ding H, Zhou L, Zeng Q, Yu Y, Chen B. 2018. Heterologous expression of a thermostable $\beta$-1, 3-galactosidase and its potential in synthesis of galactooligosaccharides. Mar. Drugs. 16(11). pii: E415.

63. Park MS, Shin DW, Lee KH, Ji GE. 1999. Sequence analysis of plasmid pKJ50 from Bifidobacterium longum. Microbiology 145: 585-592.

64. Park SY, Ji GE, Ko YT, Jung HK, Ustunol Z, Pestka JJ. 1999. Potentiation of hydrogen peroxide, nitric oxide, and cytokine production in RAW 264.7 macrophage cells exposed to human and commercial isolates of Bifidobacterium. Int. J. Food Microbiol. 46: 231-241.

65. Park M-S, Moon H-W, Ji GE. 2003. Molecular characterization of plasmid from Bifidobacterium longum. J. Microbiol. Biotechnol. 13: $457-462$. 